\title{
Determinants of bridging loan among small and medium-sized enterprises in the South African Construction Industry.
}

Olanrewaju Abdul Balogun. Nazeem Ansary and Justus Ngala Agumba

* Department of Construction Management and Quantity Surveying, University of Johannesburg, South Africa. Cnr Siemert and Beit Street Doornfontein, Johannesburg, Gauteng 2017, South Africa.

\begin{abstract}
Small and medium construction enterprise (SMEs) has become the significant clout of sustained, instantaneous and bracing growth of South Africa economy. Moreover, SMEs has performed an unparalleled role in advancing the South Africa economic growth, and serve as a breeding ground for entrepreneurs and a provider of solutions to address the problems of unemployment in all consuming labours and promoting marketing growth. An opportunity for the healthy advancement of small and medium-sized enterprises (SMEs) in South Africa was in relation to the transformation and expansion policy due to the brisk evolution of the global economy. But with the global economic integration, the small and medium-sized enterprises operating environment is facing tremendous changes and more intense competition. The data was obtained using questionnaire survey. 179 small and medium contractors responded from conveniently sampled respondents in Gauteng province in South Africa. The data was analysed using Statistical Package for the Social Sciences (SPSS) version 22. The study found that the dependant variable i.e. business bridging loan was only predicted with locality of the business. However, the other independent variables modelled with business bridging loan i.e. gender, age group, current position, type of organization ownership, tax number and collateral were not good predictors of the business bridging loan. The finding informs financial institutions not to force clients to submit collateral before awarding credit to the SMEs. The suggested model that was tested attained the Hosmer and Lemeshow Test goodness of fit. Hence the results were credible. However, a further study is proposed for the entire country as the researchers acknowledge limitation on the locality of study. This will enable the researchers to generalize the findings.
\end{abstract}

Keyword: Determinants, bridging loan, small and medium, bridging loan, construction industry, South Africa

\section{INTRODUCION}

In the South African context in the construction industry, small enterprise is defined as

having less than 50 employees, having an annual turnover of less than R5million, while medium enterprises have between 51 and 200 employees and less than R20million turnover.[31]National Business Act, 2004. SMEs contribute immensely to the gross domestic product of most countries including South Africa.
Despite their importance to the economy in South Africa, small and medium construction enterprises (SME) sector is described as largely underdeveloped and lacking the managerial and technical skills and sophistication enjoyed by larger well established firms [15]. [28] opined that lack of knowledge including knowledge of pricing procedures, contractual rights and obligations; law, management techniques and principles as well as technology were a challenge to SMEs.

Furthermore, SMEs are more likely to have limited formal education, which is based on a construction craft or trade training such as carpentry, plumbing, electrical installation and bricklaying. This training is probably in the form of learnership [12]. Past studies in South Africa revealed constraints and challenges of capacity and financial resources among SMEs.[20];[3]. [23] and [23] inferred that SMEs are not able to access finance or credit hence it stifles their growth and capability.

The concept of credit has been in existence as long as there has been civilization. It predates, by a considerable length of time the use of money, and written references to it appear as far back as in the code of Hammurabi, established around 1750 B.C. From its beginnings, credit has been used as a selling tool, to bind customers to a particular vendor and allow them to acquire more substantial goods for which they do not have the necessary capital [27]. The theory of credit emphasizes that financial institutions would be more willing to extend credit if, in case of default, they could easily enforce contracts by forcing repayment or seizing collateral. The amount of credit in a country would depend to some extent on the existence of legislation that protects the creditors' rights on proper procedures that lead to repayment [2].

\subsection{PROBLEM STATEMENT}

In spite of the role of SMEs in the South African economy, the financial restraints they face in their operations are daunting and this has had a negative impact on their development and also limited their potential to drive the national economy as expected. This is worrying for a developing economy without the requisite infrastructure and technology to attract big businesses in large numbers.

Construction SMEs in the South Africa lack the ability in terms of qualified personnel to manage their activities. As a result, they are unable to publish the same quality of financial information as those big firms and as such are not able to provide audited financial statement, 
which is one of the essential requirements in accessing bridging loan from the financial institution. This is buttressed by the statement that privately held firms do not publish the same quantity or quality of financial information that publicly held firms are required to produce. As a result, information on their financial condition, earnings, and earnings prospect may be incomplete or inaccurate. Faced with this type of uncertainty, a lender may deny credit, sometimes to the firms that are credit worthy but unable to report their results [13].

These are some of the factors already acknowledged by some researchers as hindering most SMEs in accessing bridging loan from the financial institution in the South Africa. But are these really the case in South Africa? Construction SMEs in South Africa do not also have the luxury of a financing scheme that will be appropriate for their businesses. The major type of financing open to them is debt financing from the financial institutions, which most often comes with a long list of requirements that most SMEs find them difficult to meet. The other type that is Asset financing, aside the long list of criteria also requires operators of SMEs to provide $50 \%$ of the funds and the financing institution providing the other half to fund the purchases of the assets. This type of financing do not allow for growth of the SMEs sector since they are all short term in nature.

The initial capital and expansion capital fund for South Africa construction SMEs has been a perpetual problem even though the government continuously strives to empower this sector into the mainstream economy. Credit accessibility still exists between the supply capabilities of financing sources and the demand needs for capital for construction SMEs. It is accepted that construction SMEs are a vehicle of economic empowerment in the construction industry in South Africa. However, they are faced with a plethora of challenges to be able to maximize their economic potential. Furthermore, construction SMEs find it difficult to access credit in the form of business brigding loant they apply for. It can be unequivocally indicated that there is lack of studies to determine the predictors determining business brigding loant accessibility by construction SMEs. Based on this discussion this study is guided by two specific research questions and objectives: viz;

- What are the personnel factors and firm factors that influence business bridging loan among SMEs from financial institutions? and

- What are the factors the prevent construction SMEs from accessing credit?

Therefore the objectives of the study are:

- To determine the personnel factors and firm factors that influence business bridging loan among SMEs from financial institutions: and

- To determine the factors that prevent construction SMEs from accessing credit.

\section{BRIDGING LOAN}

Bridging loans are the most common form of external financing available to businesses. Used properly, they provide a simple and effective way of financing the growth of your business. Despite their widespread use, they are not always used wisely. Many businesses make the wrong choices or incur unnecessary costs. At best, this raises the cost of financing. At worst, the business runs the risk of failure [16]. An brigding loant is the ideal way to manage your cash flow. It is linked to your business account and you can use as much as you need, up to your limit suggested by the financial institution [37]. According to the First National Bank in South Africa [21] the business bridging loan benefits are:

- It is linked to your Business Account and provides the ability to make payments even when there are no cash funds available in your account, thus avoiding penalty fees and additional charges;

- $\quad$ No minimum monthly payment as long as you remain within the agreed limit;

- Payments into the bridging facility make funds available for use again;

- Flexibility, as you can deal with unexpected expenses and capitalise on any opportunities; and

- Monthly repayments are based on the amount of credit you used.

According to [37] the benefits of business bridging loan are;

- An bridging loan is quick and easy to arrange;

- The cash is available when you need it;

- You only pay interest on what you use, not on the full amount of your limit; and

- Sole proprietors can apply for an bridging loan or increase their limits at an Auto-Plus, via Internet Banking, Cellphone Banking or by calling $0861012345 / 0860109075$.

Despite the benefits suggested. A fee of $1.2 \%$ is levied on the unutilized portion of the business banking bridging loan facilities. This fee will be accrued daily and recovered monthly [37].However, the[21] indicates that FNB customers applying for business bridging loan of less than R400000.00 are not required to submit supporting documentation or collateral. In case of business bridging loan of more than R400000.00 the FNB bank will require the following documents in order to process the credit.

- Security/collateral (customer dependent);

- A business finance application;

- Signed financial information (annual financial statements and year-to-date management accounts); and

- Projections (cash flow statements, income statements and balance sheets).

For non-FNB customers the following are the requirements:

- Six months' bank statements;

- $\quad$ Security/collateral (may be required);

- A business finance application;

- Signed financial information (annual financial statements and year-to-date management accounts);

- $\quad$ Projections (cash flow statements, income statements and balance sheets);

- A business plan to demonstrate the viability and sustainability of the business; and

- Should your application be successful, you are required to open an FNB Business Account. 


\section{LITERATURE REVIEW}

\subsection{CONSTRAINTS FACED BY CONSTRUCTION SMES IN ACCESSING BRIDGING LOAN.}

According [1] indicates that access to business bridging loan by construction SMEs has been an issue repeatedly raised by numerous studies as a major constraint to industrial growth. A common explanation for the alleged lack of access to bank bridging loan by SMEs is their inability to pledge acceptable collateral. SMEs in general face more challenges in doing business than large enterprises because of the difficulties in financing start-up and expansion. Another study by [32] found that small firms tend to experience more difficulties than medium-sized firms, which also experience more difficulties than large firms. In most countries, especially developing nations, lending to small businesses and entrepreneurs remain limited because financial intermediaries are apprehensive about supplying credit to businesses due to their high risk, small portfolios, and high transaction cost.

According to[1] on cost of transaction contributes to the inability of the SMEs to access bridging loan. They are of the opinion that "if transaction cost of lending are high the net margin banks expect from bridging loans operation do not compare favourably against safe investment represented by treasury bonds. Aryeetey study on access to credit in [7] also shares the same view that if a lender face information asymmetry, the issue often becomes somewhat persuasive authority he or she holds in ensuring repayment. These push up transaction cost as the probability of default is assumed to be high and has to be contained. Thus lenders may avoid lending to smaller or lesser known clients or impose strict collateral requirements when they do. They may perceive clients in ways that would overcome the latter own perception of the difficulty in obtaining formal finance. [5], results, on the factors that stifle SMEs from accessing bridging loan are, management expertise, high default rate and monitoring as the challenges banks faced in giving bridging loan to SMEs[32]found that financial activities such as business registration, documentation/recording, business planning, asset ownership, impact heavily on SMEs access to bank credits.

According to [10] found that the key challenges that make it difficult for SMEs to access bridging loan, include policy regulation, inadequate financial infrastructure, stringent collateral security requirement, and lack of institutional capacity of SMEs sector. The key barriers identified include informational barriers, lack of managerial skills within SMEs. [24] argued that factor like availability and cost of finance are the most common constraints faced by SMEs. Others are lack of collateral, informational barriers, regulations and rules that impede construction firms access to finance, the legal framework and policies around investment and financial institutions (FI's) lending are fundamental, lack of access to appropriate technology, weak institutional capacity, lack of management skills and training in the construction firms, and lack of proper book keeping.

The legal and regulatory frameworks that exist in Ghana also fail to provide the right support infrastructure to facilitate SMEs lending by the financial institutions. The lack of collateral, lack of proper financial management, lack of fiscal incentives for
SMEs, strict prudential regulations which restrict flexibility of FI's, unduly complex or onerous administrative procedures and even simply the lack of a consistent definition or enabling law for SMEs are some of the impediments to SMEs financing. Even though SMEs tend to attract motivated managers, they can hardly compete with larger firms.

[16] reviewed that entrepreneurs face several problems in their efforts to access finance, particularly from banks; viz., lack of collateral security, refusal to use own collateral, failure to make a remarkable own contribution, blacklisting, failure to review attractive financial records and/or business plans and high risk of small entrepreneurs.[19] explicates that lack of collateral is the most widespread problem, particularly if the entrepreneur is applying for working capital. Other issues affecting the decision to provide finance include blacklisting, and inadequate financial records. The report concluded that, based on international comparisons, for a significant proportion of unsuccessful applicants, the failure of the application would not seem to be entirely unreasonable.

The Organization for Economic Cooperation and Development [34] argued that banks may avoid providing finance to certain types of SMEs, in particular, start-ups and very young firms that typically lack sufficient collateral, or firms whose activities offer the possibilities of high returns but at a substantial risk of loss [34]. It can be suggested from these discussions that different set of challenges prevents SMEs from accessing finance. Hence, the importance of determining the challenges faced by SMEs in the South Africa construction industry from accessing credit.

\section{PREDICTORS OF BRIDGING LOAN FOR CONSTRUCTION SMES}

[20] in his study indicated that the availability of business plan, collateral, maintenance of a good relationship, managerial competency and a good credit score are critical lending requirements. In a study conducted by [26]in Tanzania, they found that there is interdependence and significant relationship between the firms characteristics i.e. location, industry, incorporation, age, size, availability of business information and collateral and access of debt to financing by SMEs.

According to [18] and [18] their findings suggested that education, distance to credit source and types of credit source as major factors that influenced farmers' access to agricultural credit. In a study by [11] and [11] in South Africa they established that access to credit was negatively influenced by educational achievement, investment in production costs, access to market information and membership of cooperative. In a separate study by [11] they found that the predictors for credit accessibility by smallholder farmers were, attitude towards risk, distance between lender and borrower, perception on loan repayment, perception on lending procedures and total value of assets. [11] and [33] posited that gender, marital status, lack of guarantor, high interest rate predicted access to credit among rural framers in Nigeria.

[19[and[19]results indicate that managerial competencies, business information, networking, location, crime, business size and incorporation are significant determinants of credit approval.[17],[17], [17], in their study established that extension contact, 
education level and saving habit had significant positive influence on farmers' access to formal credit. [25] and [25] opined that the key factors that influenced credit rationing by commercial banks in Kenya are loan characteristics, firm characteristics and observable characteristics. The study established that most of the banks rationed credit in order to reduce risk and to avoid the risk of adverse selection and moral hazard.[9]found that banks in developing economies, compared to those in developed economies, tend to be less exposed to SMEs, hence charge them higher interest rates and fees.

[30] and [30] inferred that profile such as ownership structure; size of the firm; business type; and age of the business indeed influence SMEs' access to finance. [5] and [5], results indicated that, the number of employees, experience in credit use and number of fixed assets possessed, attitude towards risk, business size, sector and form of business in the economy are the critical success factors in accessing bank finance. In a study by [36]using chi square as statistical parameter, found that, education of the entrepreneur and having membership with business association are associated with access to bank finance. In view of these discussions there is no consensus of a set of determinants that will predict access to credit. Furthermore, no study has focused specifically on business bridging loan accessibility from the financial institutions. Hence, this research poses the question:

- What are the personnel factors and firm factors that influence business bridging loan for construction SMEs from financial institutions?

\section{RESEARCH METHOD}

A structured questionnaire survey was used to collect data. Creswell (1994) describes a survey as a quantitative or numeric description of some fraction of the population - the sample. This enables the researcher(s) to generalize their findings from a sample of respondents to a population within the limitations of the sampling method. Convenience sampling was used which consisted of contractors registered with the [14. A total of 179 SMEs completed the questionnaire survey. Content validity was conducted on the questionnaire using pilot study administered to 30 construction SMEs.

SPSS version 22 was used to perform the binary logistic regression analysis. A binary logistic regression model with a dichotomous dependent variable of Yes or No was modelled. Yes response was defined as having accessed business bridging loan and No did not access business bridging loan. The dependent variable was coded as 1 and 0 , for "Yes" and "No" respectively. The independent variables of the logistic regression model were also coded and were categorical. They were the personnel profile and the firms demographic characteristics of the SMEs: gender if male 1 and female 2; age group, 30 years and below 1, 31 years to 39 years 2, 40 years to 49 years 3 and 50 years and above 4; current position, director 1 , owner 2 , manager 3 and manager/owner 4; ownership, sole proprietorship 1, partnership 2, limited partnership 3, limited Liability company 4, corporation (for-profit) 5; tax number No, 0 and Yes, 1; location of business, city of Johannesburg Metropolitan Municipality 1, city of Tshwane Metropolitan Municipality 2, Ekurhuleni Metropolitan Municipality 4, West Rand District Municipality 4; collateral No, 0 and Yes, 1. Logistic regression is recommended over linear regression when modeling dichotomous responses and allows the researcher to estimate probabilities of the response occurring (Hosmer and Lemeshow, 2004). The logistic regression equation takes the following form

$\ln (\mathrm{p} / 1-\mathrm{p})=\beta 0+\beta 1 \mathrm{x} 1+\beta 2 \times 2+\ldots+$

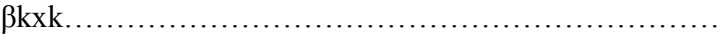
..(1.1)

Where $\mathrm{p}$ is the estimated probability of passing, and $\mathrm{x} 1$, $\mathrm{x} 2 \ldots \ldots \ldots \ldots \ldots \ldots \ldots \ldots \ldots \ldots \ldots \ldots$ are independent variables.

The estimated probability of the response occurring or passing $(\mathrm{p})$ divided by the probability of it not occurring or not passing (1-p) is called the odds ratio. Maximum likelihood method is used to estimate the odds ratios of the model. Values of odds ratios higher than 1 indicate positive association between the variables, odds ratios equal to 1 indicate no association, while odds ratios lower than 1 indicate negative association between each independent variable and the dependent variable of the model.

Furthermore, in order for an independent variable to be a predicator of the dependent variable the p-value should be less than 0.05 at $95 \%$ confidence, which connotes its significance in the model. In achieving a fitting model the Hosmer-Lemeshow goodness of fit test should be significant i.e. the value should be greater than 0.05 [35]. It can be indicated that the model tested achieved the Hosmer-Lemeshow goodness of fit test at 0.91 .

\section{RESULTS AND DISCUSSIONS}

The result in Table 4.0 infers that of the 179 respondents 13 i.e. $7.26 \%$ of SMEs surveyed obtained the business bridging loan they applied for. 166 of the SMEs i.e. $92.74 \%$ did not either apply for the business bridging loan or got the business bridging loan. This is imperative to this study as there is lack of studies that have determined the predicators that influence business bridging loan globally.

Table 4.0 Business bridging loan accessed

\begin{tabular}{|c|c|c|}
\hline $\begin{array}{c}\text { Accessed the } \\
\text { credit }\end{array}$ & Respondents & Percentage \\
\hline Marked & 13 & $7.26 \%$ \\
\hline Unmarked & 166 & $92.74 \%$ \\
\hline Total & $\mathbf{1 7 9}$ & $\mathbf{1 0 0 . 0 0 \%}$ \\
\hline
\end{tabular}

The result in Table 4.1, suggests that of the seven independent variables i.e. gender, age, location of business, type of business ownership, tax number, current position in the company and collateral or security modelled to predict business bridging loan or credit accessibility. The locality of the business predicted business bridging loan. Those businesses that are located in the West Rand municipality of Gauteng province in South Africa were likely to receive business bridging loan/ credit than businesses that were located in the city of Johannesburg. The level of significance was less than 0.05 at 0.049 hence indicating a strong predictor. The odd of getting the bridging loan was 6.105. It can further be suggested that we are $95 \%$ confident that the actual value of odds ratio in the population lies somewhere between 1.01 and 37.01. Further, because the confidence intervals does not contain the value of 1.00 , this result is statistically significant at $<0.05$. This finding 
corroborates with the study of [19] conducted in South Africa. However, there study focused on generic credit not a specific type of credit. This finding suggests that financial institutions might only consider businesses in West Rand municipality when SMEs apply for business bank bridging loan for their business.

The results in Table 4.1 further indicate that the gender, age, type of business ownership, tax number, and current position in the company were not predicting the business bridging loan or credit accessibility. The level of significance of these variables was greater than 0.05 , hence poor predictors. The result on the gender of the applicant is not in line with the finding of [33] and [33] as a predictor. [26] and [26]in Tanzania, established that the location and collateral were predicators of business credit accessibility. However, this current study did not support their findings. Furthermore, it is imperative to mention that collateral was not statistically interpreted in the output result of SPSS despite being included in the analysis as a predicting variable.

However, prior to testing this model, the goodness of fit of the model was tested which indicated a good fit. This result was justified by the Hosmer and Lemeshow test. The significance of the model was greater than 0.05 at 0.913 . The result suggests that the independent variables were fitting in the proposed theoretical model.

Table 4.1 Predictors of accessing business bridging loan

\begin{tabular}{|c|c|c|c|c|}
\hline Variable & $\begin{array}{l}\text { Exp. (B) } \\
\text { Odds } \\
\text { ratio }\end{array}$ & $\begin{array}{l}95 \% \\
\text { C.I. for } \\
\text { EXP } \\
\text { (B) } \\
\text { Lower }\end{array}$ & $\begin{array}{l}95 \% \\
\text { C.I. } \\
\text { for } \\
\text { EXP } \\
\text { (B) } \\
\text { Upper }\end{array}$ & $\begin{array}{l}\text { P- } \\
\text { value }\end{array}$ \\
\hline Gender (1) & 1.685 & 0.489 & $\begin{array}{l}5.80 \\
5\end{array}$ & $\begin{array}{l}0.40 \\
9\end{array}$ \\
\hline Age group & & & & $\begin{array}{l}0.90 \\
7\end{array}$ \\
\hline $\begin{array}{l}\text { 31-40 years } \\
\text { (1) }\end{array}$ & $\begin{array}{l}3533670 \\
6.514\end{array}$ & 0.000 & . & $\begin{array}{l}0.99 \\
9\end{array}$ \\
\hline $\begin{array}{l}\text { 40- } 49 \text { years } \\
\text { (2) }\end{array}$ & $\begin{array}{l}3521612 \\
2.305\end{array}$ & 0.000 & . & $\begin{array}{l}0.99 \\
9\end{array}$ \\
\hline $\begin{array}{l}50 \text { years and } \\
\text { over }(3)\end{array}$ & $\begin{array}{l}5917709 \\
8.015\end{array}$ & 0.000 & . & $\begin{array}{l}0.99 \\
9\end{array}$ \\
\hline $\begin{array}{l}\text { Current } \\
\text { position }\end{array}$ & & & & $\begin{array}{l}0.33 \\
9\end{array}$ \\
\hline Owner (1) & 0.309 & 0.088 & $\begin{array}{l}1.08 \\
4\end{array}$ & $\begin{array}{l}0.06 \\
7\end{array}$ \\
\hline Manager (2) & 0.000 & 0.000 & . & $\begin{array}{l}0.99 \\
9\end{array}$ \\
\hline $\begin{array}{l}\text { Manager/ow } \\
\text { ner (3) }\end{array}$ & 0.000 & 0.000 & . & $\begin{array}{l}1.00 \\
0\end{array}$ \\
\hline Ownership & & & & $\begin{array}{l}1.00 \\
0\end{array}$ \\
\hline $\begin{array}{l}\text { Partnership } \\
\text { (1) }\end{array}$ & 0.000 & 0.000 & . & $\begin{array}{l}0.99 \\
9\end{array}$ \\
\hline $\begin{array}{l}\text { Limited } \\
\text { partnership } \\
\text { (2) }\end{array}$ & 0.000 & 0.000 & . & $\begin{array}{l}1.00 \\
0\end{array}$ \\
\hline $\begin{array}{l}\text { Limited } \\
\text { Liability } \\
\text { company } \\
(\text { LLC) (3) }\end{array}$ & 0.000 & 0.000 & . & $\begin{array}{l}1.00 \\
0\end{array}$ \\
\hline
\end{tabular}

Continuation Table 4.1 Predictors of accessing business bridging loan

\begin{tabular}{|c|c|c|c|c|}
\hline Variable & $\begin{array}{l}\text { Exp. } \\
\text { (B) } \\
\text { Odds } \\
\text { ratio }\end{array}$ & $\begin{array}{l}95 \% \\
\text { C.I. for } \\
\text { EXP } \\
\text { (B) } \\
\text { Lower }\end{array}$ & $\begin{array}{l}95 \% \\
\text { C.I. for } \\
\text { EXP } \\
\text { (B) } \\
\text { Upper }\end{array}$ & P-value \\
\hline $\begin{array}{l}\text { Tax number } \\
\text { (1) }\end{array}$ & $\begin{array}{l}59799 \\
061.7 \\
29\end{array}$ & 0.000 & . & 0.999 \\
\hline $\begin{array}{l}\text { Location } \\
\text { (municipalit } \\
\text { y) }\end{array}$ & & & & 0.265 \\
\hline $\begin{array}{l}\text { City of } \\
\text { Tshwane } \\
\text { Metropolita } \\
\text { n } \\
\text { Municipality } \\
\text { (1) }\end{array}$ & 3.733 & 0.618 & 22.533 & 0.151 \\
\hline $\begin{array}{l}\text { Ekurhuleni } \\
\text { Metropolita } \\
\text { n } \\
\text { Municipality } \\
\text { (2) }\end{array}$ & 2.979 & 0.454 & $\begin{array}{l}19.53 \\
2\end{array}$ & 0.255 \\
\hline $\begin{array}{l}\text { West Rand } \\
\text { District } \\
\text { Municipality } \\
\text { (3) }\end{array}$ & 6.105 & 1.007 & $\begin{array}{l}37.00 \\
9\end{array}$ & 0.049 \\
\hline & 0.000 & & & 0.999 \\
\hline
\end{tabular}

Dependent variable: business bridging loan accessibility $(0=$ unmarked; $1=$ marked $)$ sig. at $5 \%$

\section{CONCLUSIONS AND RECOMMENDATIONS}

The study found that construction SMEs are constraint from accessing bridging loan because of lack of collateral/security, lack of cash flow statement and owners' equity. High interest rate was also deemed to be a factor preventing SMEs accessing bridging loan. These factors might deter the construction SMEs business owners not to approach financial institutions but rather request family and friend to support them in acquiring credit/loan.

The researchers established that for construction SMEs to access business bridging loan, the location of the business was an imperative factor. The business located in West Rand had a higher probability of accessing the business bridging loan than those located in the city of Johannesburg. it is interesting to conclude that, gender, age, type of business ownership, tax number, current position in the company and collateral or security modelled to predict business bridging loan/credit accessibility were insignificant. This finding should be interpreted with caution as construction SMEs from Gauteng were the only respondents who participated. It is opined that the results might be different if the survey was conducted within construction SMEs in all the nine provinces in South Africa. Based on these findings, the researchers recommend that:

Construction SMEs should provide, the requirements requested by the financial institutions as they apply for the business bridging loan/credit. However, the study informs the financial institutions that, gender, age, current position of the applicant and the business profile and requirements i.e. the tax number, collateral and type of business ownership are not a panacea in acquiring business bridging loan.

In relation to the findings, the researchers propose the need to use other socio-economic and demographic characteristics that were not used in this 
study as the current factors are not exhaustive in relation to the full characteristic of SMEs. The factors recommended for testing are marital status of the applicant, bank account statement and managerial ability of the respondents.

\section{REFERENC}

[1] Abor, J, / Biekpa, N, (2005) - Corporate debt policy of Small and Medium Enterprises in Ghana: University of Stellenbosch, South Africa.

[2] Aduda, J., Magutu, O.P. and Wangu, G.M., 2012, The Relationship between Credit Scoring Practices by Commercial Banks and Access to Credit by Small and Medium Enterprises in Kenya, International Journal of Humanities and Social Science, 2, 9, 203-213.

[3] Agumba, J.N., Adegoke, I.O. and Otieno, F.A.O., 2005, Evaluating Project Management Techniques in Small and Medium Enterprises Delivering Infrastructure in South Africa Construction Industry. Proceedings of 3rd Postgraduate Conference 2005, Construction Industry Development, Eskom Convention Center, Midrand, Johannesburg, South Africa, 9th-11th October, 52-65.

[4] Agumba, N.J., (2006), evaluating the use of Project Management Techniques in Infrastructure Delivery by South African Small and Medium Sized Contractors. Unpublished Masters Dissertation, Faculty of Engineering and the Built Environment, University of Johannesburg, South Africa.

[5] Alhassan, F. and Sakara, A., 2014, Socio-Economic Determinants of Small and Medium Enterprises' (Smes) Access to Credit from the Barclays Bank in TamaleGhana, International Journal of Humanities \& Social Science Studies, I, II, 26-36

[6] Angela and Motsa Associates, 2004, SMME Finance Sector Background Paper: A Review of key documents on SMME Finance 1994-2004. Fin Mark Trust: Johannesburg.

[7] Aryeetey, E.A, Baah-Nuakoh, A., Duggleby, T., Hettige H., and Steel, W.F (1994), Supply and Demand for Finance of Small Enterprises in Ghana, Discussion Paper No. 251, Technical Department, Africa Region. Washington, D.C., World Ban

[8] Ayyari M., Thorsten, B. and Demirguck-Kunt A., August, 2003, Small and Medium Enterprises across the Globe: A New Database. The World Bank Development Research Group.

[9] Beck, T., Asl1, D-K. and Maria S.M.P., 2008, Bank Financing for SMEs around the World: Drivers, Obstacles, Business Models, and Lending Practices, Policy Research Working Paper 4785. World Bank, Washington, DC.

[10] Bondinuba, F.W., 2012, Exploring the Challenges and Barriers in Accessing Financial Facilities by Small and Medium Construction Firms in Ghana, Civil and Environmental Research, 2, 6, 25-35.

[11] Chauke, P.K. and Anim, F.D.K., 2013, Predicting Access to Credit by Smallholder Irrigation Farmers: A Logistic Regression Approach, Journal of Human Ecology, 42, 3, 195-202.

[11] Chauke, P.K., Motlhatlhana, M.L., Pfumayaramba, T.K. \& Anim, F.D.K., 2013, Factors influencing access to credit: A case study of smallholder farmers in the Capricorn district of South Africa, African Journal of Agricultural Research, 8, 7, 582-585.
[12] Construction Industry Development Board, 2008, Construction Health and Safety in South Africa, Status and Recommendations. Pretoria, South Africa.

[13] Coleman, S. (2000), 'Access to Capital and Terms of Credit: A Comparison of Men and Women-Owned Small Businesses', Journal of Small Business Management, 38(3), pp. 37-52

[14] Creswell, J.W., 1994, Research design, qualitative and quantitative approaches. London: Sage.

[15] Department of Public Works, 1999, White paper on Creating an Enabling Environment for Reconstruction Growth and Development in the Construction Industry, Government Printers, Republic of South Africa. http://www.info.gov.za/whitepaper/1999/environment.ht $m$ last accessed on the 01/02/2015.

[16] Director's breifing (n.d.) Brigding loants and bank loans, available from http://www.icaew.com/ /media/corporate/files/library/co llections/online\%20resources/briefings/directors\%20brief ings/fi1 overd.ashx, accessed on 05/08/2016

[17] Dzadze, P., Osei Mensah, J., Aidoo, R. \& Nurah, G. K., 2012, Factors determining access to formal credit in Ghana: A case study of smallholder farmers in the Abura-Asebu Kwamankese district of central region of Ghana, Journal of Development and Agricultural Economics, 4, 14, 416-423.

[18] Etonihu, K.I., Rahman, S.A. and Usman, S., 2013, Determinants of access to agricultural credit among crop farmers in a farming community of Nasarawa State, Nigeria, Journal of Development and Agricultural Economics, 5, 5, 192-196.

[19] Fatoki, O. and Odeyemi, A., 2010, Which New Small and Medium Enterprises in South Africa Have Access to Bank Credit? International Journal of Business and Management, 5, 10, 128-136.

[20] Fatoki, O., 2014, Factors Influencing the Financing of Business Start-ups by Commercial Banks in South Africa, Mediterranean Journal of Social Sciences, 5, 20, 94-100.

[21] First National Bank (n.d.), Business brigding loant, available from https://www.fnb.co.za/businessbanking/accounts/brigding loant.html, accessed on the 05/08/2016.

[22] Foxcroft, M., E. Wood, J. Kew, M. Herrington and N. Segal, 2002, Global Entrepreneurship Monitor: South African Executive Report, Graduate School of Business: University of Cape Town.

[23] Grimsholm, E., and Poblete, L., 2011, Internal and External factors hampering SME growth-A qualitative case study of SMEs in Thailand- unpublished masters thesis, Gotland University.

[24] Kayanula, D. \& Quartey, P., 2000, The Policy Environment for Promoting Small and Medium-Sized Enterprises in Ghana and Malawi, Finance and Development Research Programme, Working Paper Series, Paper No 15, IDPM, University of Manchester.

[25] Kimutai, C.J. and Ambrose, J., 2013, Factors Influencing Credit Rationing by Commercial Banks in Kenya, International Journal of Humanities and Social Science, 3, 20, 244-252.

[26] Kira, R.A., and He, Z., 2012, The Impact of Firm Characteristics in Access of Financing by Small and Medium-sized Enterprises in Tanzania, International Journal of Business and Management, 7, 24, 108-119.

[27] Mandell, L., 1994, The Credit Card Industry: A History, Boston, Twayne Publishers.

[28] Martin, 1. 2010, Challenges faced by South African 
emerging contractors- review and update. Proceedings of the Construction, Building and Real Estate Research conference of Royal Institute of Chartered Surveyors, Dauphine Universite, Paris 2nd-3rd September, France.

[29] Mazanai M., and Fatoki, O., (2011), Access to Finance in the SME Sector: A South African Perspective, Asian Journal of Business Management 4, 1, 58-67.

[30] Musamali, M.M., and Tarus, K.D., (2013), Does firm profile influence financial access among small and medium enterprises in Kenya? Asian Economic and Financial Review, 3, 6, 714-723.

[31] National Small Business Act. 2004, Number 29 of 2004 Republic of South Africa. Available from: http://www.info.gov.za/view/DownloadFileAction?id=67 967 last accessed 18/04/2016.

[32] Nkuah, K.J., Tanyeh, P.J., and Gaeten, K., 2013, financing small and medium enterprises (SMEs) in Ghana: Challenges and determinants in accessing bank credit, International Journal of Research in Social Sciences, 2, 3, 12-25.

[33] Ololade, R.A. and Olagunju, F.I., 2013, Determinants of Access to Credit among Rural Farmers in Oyo State, Nigeria, Global Journal of Science Frontier Research Agriculture and Veterinary Sciences 13, 2, 1, $17-22$.

[34] Organization for Economic Cooperation and Development (OECD, 2006), The SMEs Financing Gap Volume 1: Theory and Evidence. Retrieved from: http://ec.europa.eu/enterprise/newsroom/cf/document.cf $\mathrm{m}$ ?action $=$ display $\&$ doc $-\mathrm{id}=624 \&$ userservice accessed on the 11/03/2016

[35] Pallant, J. 2013, SPSS, Survival Manual: A step-bystep guide to data analysis using IBM, SPSS, 5th Edition, Allen \& Unwin, Sydney, Melbourne, Auckland, London.

[36] Pendula, G., 2011, An Empirical Investigation of Small And Medium Enterprises' Access to Bank Finance: The Case of an Emerging Economy. loan and finance/Business-Brigding loant accessed on the 05/08/2016

[37]Standard Bank South Africa(n.d.b), business Brigding loant, available from http//www.standardbank.co.za/stanardbank/Business/Loa nd-and-finance/Business-Brigding loant accessed on the $05 / 08 / 2016$

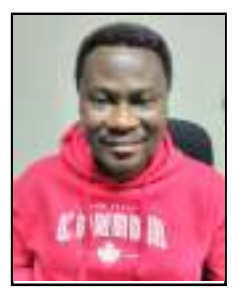

Olanrewaju Abdul Balogun. (BSc, MTech, Dip, ASME) Holds a Bachelor's of Science in Building science from University of Lagos, Master Degree in Construction Management University of Johannesburg South Africa, Diploma in Project, Diploma in Blocking and Concreting and also a Member of American Society of Mechanical Engineers, Member Nigerian Institute of Building and has many years of working experience in the Construction Industry, Among orders are Telecommunication, Oil and Gas Industry. $\mathrm{He}$ is currently a lecturer and academic researcher at the Department of Construction Management and Quantity Surveying, University of Johannesburg. He has published extensively in various refereed conferences and has also presented papers in many international conferences all over the world. His main research interests are construction project management, construction management and finance management in construction.

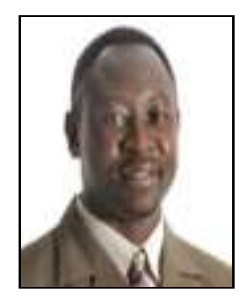

Justus N. Agumba (PhD, MTech, BTech, PrCM, MCIOB, MAQS) holds a Bachelor's Degree in Construction Management and Quantity Surveying and also obtained in 2006 his Master's Degree in Construction Management, from University of Johannesburg, South Africa. In 2013, he received his $\mathrm{PhD}$ in Engineering Management, from University of Johannesburg, South Africa. He is a Professional Construction Manager, and also a Member of the Association of South African Quantity Surveyors and has many years of working experience in the Construction Industry. He is currently a Senior lecturer and academic researcher at the Department of Construction Management and Quantity Surveying, University of Johannesburg. He has published extensively in various refereed journals and has also presented papers in many international conferences all over the world. His main research interests are construction project management, construction management, risk management and Health and Safety in construction.

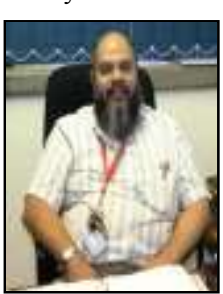

Nazeem Ansary (NHD, BTech QS MCPM, PrQS, PMAQS, MRICS, FCIOB) holds a National Higher Diploma in Building Surveying and Bachelor's Degree in Quantity Surveying from Cape Peninsula University of Technology, South Africa and Tshwane University of Technology respectively. He received in 2010 his Master's Degree, Master of Construction Project Management from University of New South Wales, Australia. He is a Professional Quantity Surveyor and has many years of working experience in the construction industry and currently working as a senior lecturer and Head of Department Construction Management and Quantity Surveying at the University of Johannesburg, South Africa. He has published several accredited articles in refereed journals and has presented papers in many international conferences all over the world. His main research interests are construction project management, construction management, dispute resolution, risk management in construction. 